\title{
Study of electron transition energies between anions and cations in spinel ferrites using differential UV-vis absorption spectra
}

L. C. Xue , L. Q. Wu ${ }^{\mathrm{a}}$, S. Q. Li ${ }^{\mathrm{a}, \mathrm{b}}$, Z. Z. Li ${ }^{\mathrm{a}}$, G. D. Tang ${ }^{\mathrm{a},{ }^{,}}$, W. H. Qi ${ }^{\mathrm{a}}$, X. S. Ge ${ }^{\mathrm{a}}$, L. L. Ding ${ }^{\mathrm{a}}$

${ }^{a}$ Hebei Advanced Thin Film Laboratory, Department of Physics, Hebei Normal University,

Shijiazhuang City, 050024, People's Republic of China

${ }^{\mathrm{b}}$ School of Sciences, Hebei University of Science and Technology, Shijiazhuang City, 050018,

People's Republic of China

\section{ABSTRACT}

It is very important to determine electron transition energies $\left(E_{\mathrm{tr}}\right)$ between anions and different cations in order to understand the electrical transport and magnetic properties of a material. Many authors have analyzed UV-vis absorption spectra using the curve $(\alpha h v)^{2}$ vs $E$, where $\alpha$ is the absorption coefficient and $E(=h v)$ is the photon energy. Such an approach can give only two band gap energies for spinel ferrites. In this paper, using differential UV-vis absorption spectra, $\mathrm{d} \alpha / \mathrm{d} E$ vs $E$, we have obtained electron transition energies $\left(E_{\mathrm{tr}}\right)$ between the anions and cations, $\mathrm{Fe}^{2+}$ and $\mathrm{Fe}^{3+}$ at the (A) and $[\mathrm{B}]$ sites and $\mathrm{Ni}^{2+}$ at the $[\mathrm{B}]$ sites for the $(\mathrm{A})[\mathrm{B}]_{2} \mathrm{O}_{4}$ spinel ferrite samples $\mathrm{Co}_{x} \mathrm{Ni}_{0.7-x} \mathrm{Fe}_{2.3} \mathrm{O}_{4}(0.0 \leq x \leq 0.3), \mathrm{Cr}_{x} \mathrm{Ni}_{0.7} \mathrm{Fe}_{2.3-x} \mathrm{O}_{4}(0.0 \leq x \leq 0.3)$ and $\mathrm{Fe}_{3} \mathrm{O}_{4}$. We suggest that the differential UV-vis absorption spectra should be accepted as a general analysis method for determining electron transition energies between anions and cations.

Keywords: Spinel ferrite, Crystal structure, UV-vis absorption spectra, Electron transition energy

${ }^{*}$ Corresponding author, Tel.: +86 311 80787330. E-mail address: tanggd@mail.hebtu.edu.cn (G.D.Tang). 


\section{Introduction}

Recently, spinel ferrites have received considerable attention regarding their morphologies and microstructures because their novel functionalities depend not only on their compositions but also on their microstructures [1-4]. In the (A)[B] $]_{2} \mathrm{O}_{4}$ spinel ferrites, each unit cell contains eight formula units, in which the 32 larger oxygen anions form a close-packed face-centered-cubic structure with the 24 smaller metal cations occupying the two types of interstitial positions: the tetrahedral (8a) or (A) sites, and the octahedral (16d) or [B] sites [4-6].

UV-vis absorption spectra have been used to investigate the band gap energies of (A) $[\mathrm{B}]_{2} \mathrm{O}_{4}$ spinel ferrites [7-12]. Jagriti Pal et al. studied the characteristics of $\mathrm{Co}_{3} \mathrm{O}_{4}$ nanocrystals, and gave curves of $(\alpha h v)^{2}$ vs $h v$, where $\alpha$ is the UV-vis absorption coefficient, and $h v$ is the photon energy. Using this curve, they obtained two band gap energies, 2.28 and $1.57 \mathrm{eV}$. They claimed that the two band gap energies correspond to electron transitions for $\mathrm{O}^{2-} \rightarrow \mathrm{Co}^{2+}$ and $\mathrm{O}^{2-} \rightarrow \mathrm{Co}^{3+}$, respectively [7]. Applying a similar method, $\mathrm{Hu}$ et al. investigated the properties of $\mathrm{NiCo}_{2} \mathrm{O}_{4}$ nanoplates. In their research, two band gap energies were also observed, $2.0 \mathrm{eV}$ and $3.3 \mathrm{eV}$, which were ascribed to the co-existence of high-spin and low-spin states of $\mathrm{Co}^{3+}$ in the $\mathrm{NiCo}_{2} \mathrm{O}_{4}$ spinel [8]. Cui et al. estimated the band gap energies from O $2 \mathrm{p}$ to $\mathrm{Co} 3 \mathrm{~d}-\mathrm{e}_{\mathrm{g}}$ and $\mathrm{Co} 3 \mathrm{~d}_{-1} \mathrm{t}_{2 \mathrm{~g}}$ for ordinary $\mathrm{NiCo}_{2} \mathrm{O}_{4}$, and found values of 3.40 and $1.97 \mathrm{eV}$ respectively [9]. Melsheimer et al. studied the band gap energies of heteropoly compounds using differential UV absorption spectra, $\mathrm{d} \alpha / \mathrm{d} E$ vs $E$, where $E=h v$ is the photon energy [12].

In this paper, we describe how, using differential UV-vis absorption spectra, $\mathrm{d} \alpha / \mathrm{d} E$ vs $E$, we obtained the electron transition energies between anions and different cations for the (A) $[\mathrm{B}]_{2} \mathrm{O}_{4}$ spinel ferrites $\mathrm{Co}_{x} \mathrm{Ni}_{0.7-x} \mathrm{Fe}_{2.3} \mathrm{O}_{4} \quad(0.0 \leq x \leq 0.3)$, $\mathrm{Cr}_{x} \mathrm{Ni}_{0.7} \mathrm{Fe}_{2.3-x} \mathrm{O}_{4}(0.0 \leq x \leq 0.3)$ and $\mathrm{Fe}_{3} \mathrm{O}_{4}$. This is very important for understanding electrical transport and magnetic properties of a material.

\section{Experimental}

UV-vis absorption spectra for $\mathrm{Co}_{x} \mathrm{Ni}_{0.7-x} \mathrm{Fe}_{2.3} \mathrm{O}_{4}(0.0 \leq x \leq 0.3), \mathrm{Cr}_{x} \mathrm{Ni}_{0.7} \mathrm{Fe}_{2.3-x} \mathrm{O}_{4}$ $(0.0 \leq x \leq 0.3)$ and $\mathrm{Fe}_{3} \mathrm{O}_{4}$ samples were measured with a spectrophotometer (SHIMADZU, UV 3600) at room temperature in the wave length range 220-800 nm, with a maximum step size of $2 \mathrm{~nm}$. The samples of $\mathrm{Co}_{x} \mathrm{Ni}_{0.7-x} \mathrm{Fe}_{2.3} \mathrm{O}_{4}$ and 
$\mathrm{Cr}_{x} \mathrm{Ni}_{0.7} \mathrm{Fe}_{2.3-x} \mathrm{O}_{4}$ were prepared using a chemical co-precipitation method. The preparation process, heat treatment conditions, crystal structure and magnetic parameters of the samples have been reported elsewhere [13]. The $\mathrm{Fe}_{3} \mathrm{O}_{4}$ samples were obtained as commercial chemical powders, for which the crystal structure and magnetic parameters can be found in Ref. 14.

\section{Result and discussion}

The X-ray diffraction (XRD) patterns of the samples are shown in Fig. 1, and indicate that all the samples had a single-phase cubic spinel structure. The XRD data were fitted using the X'Pert HighScore Plus software with the Rietveld powder diffraction profile fitting technique [15]. Table 1 shows the results obtained for the crystal lattice constant $a$, the distances, $d_{\mathrm{AO}}$ and $d_{\mathrm{BO}}$, from the $\mathrm{O}$ anions to the cations at the $(\mathrm{A})$ and $[\mathrm{B}]$ sites, and the distance, $d_{\mathrm{AB}}$, from the cations at the (A) sites to those at the $[\mathrm{B}]$ sites. The volume averaged crystallite sizes of all samples, as estimated using the X'Pert HighScore Plus software, were larger than $100 \mathrm{~nm}$ so that surface effects are expected to be very weak in all the samples.

Fig. 2 shows the UV-vis absorption spectra of the samples in the wave length range $220-800 \mathrm{~nm}$, that is the curves of the absorption coefficient $(\alpha)$ versus wave length $(\lambda)$. It can be seen that there are different slopes at different wave lengths, which can be ascribed to the different electron transitions between the oxygen ions and cations. Using an approach similar to the method reported by Melsheimer et al. [12], we investigated the dependences of the differential absorption coefficient, $\mathrm{d} \alpha / \mathrm{d} E$, on the photon energy, $E=h v$, as shown in Fig. 3.

It can be easily seen from Fig. 3 that for the $\mathrm{Co}_{x} \mathrm{Ni}_{0.7-x} \mathrm{Fe}_{2.3} \mathrm{O}_{4}$ samples, the peak intensities at $1.64 \mathrm{eV}$ decrease gradually with decreasing $\mathrm{Ni}$ content, while for the $\mathrm{Cr}_{x} \mathrm{Ni}_{0.7} \mathrm{Fe}_{2.3-x} \mathrm{O}_{4}$ samples, in which the Ni content is constant, the corresponding peak intensities are constant. Therefore, the peaks at $1.64 \mathrm{eV}$ in Fig. 3(a) and 3(b) are ascribed to the electron transition between $\mathrm{Ni}$ and $\mathrm{O}$ ions.

It can be easily understood that the peak intensity for a specific ion in Fig. 3 is determined by the cation contents and the distance between the cation and anion. In order to identify how to ascribe the various peaks in Fig. 3 to which transitions, it is necessary to know the distribution of cations at the (A) and [B] sites as a function of the doping level $x$. Applying the $\mathrm{O} 2 \mathrm{p}$ itinerant electron model earlier proposed by our 
group, we have estimated the cation distributions for doped spinel ferrites $[13,14,16-24]$. These cation distributions for $\mathrm{Co}_{0.3} \mathrm{Ni}_{0.4} \mathrm{Fe}_{2.3} \mathrm{O}_{4}$ [13], $\mathrm{Cr}_{0.3} \mathrm{Ni}_{0.7} \mathrm{Fe}_{2} \mathrm{O}_{4}$ [13] and $\mathrm{Fe}_{3} \mathrm{O}_{4}$ [14] are shown in Table 2. It can be seen that the $\mathrm{Ni}^{2+}$ cation content at the [B] sites is more than $75 \%$ of all $\mathrm{Ni}$ cations in the two $\mathrm{Ni}$ doped samples. Therefore, the peaks at $1.64 \mathrm{eV}$ in Fig. 3(a) and 3(b) are ascribed to the electron transition between $\mathrm{Ni}^{2+}$ and $\mathrm{O}$ ions at [B] sites.

For the transition between $\mathrm{Fe}$ cations and $\mathrm{O}$ anions, on the one hand, it can be seen from Table 2 that the content ratio of Fe cations per formula at the (A) or the [B] sites, $\quad n\left(\mathrm{Fe}^{2+}{ }_{\mathrm{B}}\right) / n\left(\mathrm{Fe}^{3+}{ }_{\mathrm{A}}\right) / n\left(\mathrm{Fe}^{2+}{ }_{\mathrm{A}}\right) / n\left(\mathrm{Fe}^{3+}{ }_{\mathrm{B}}\right)=1.099 / 0.457 / 0.403 / 0.342$ for $\mathrm{Co}_{0.3} \mathrm{Ni}_{0.4} \mathrm{Fe}_{2.3} \mathrm{O}_{4}$, and $n\left(\mathrm{Fe}^{2+}{ }_{\mathrm{B}}\right) / n\left(\mathrm{Fe}^{3+}{ }_{\mathrm{A}}\right) / n\left(\mathrm{Fe}^{2+}{ }_{\mathrm{A}}\right) / n\left(\mathrm{Fe}^{3+}{ }_{\mathrm{B}}\right)=1.032 / 0.494 / 0.269 / 0.205$ for $\mathrm{Cr}_{0.3} \mathrm{Ni}_{0.7} \mathrm{Fe}_{2} \mathrm{O}_{4}$. The subscript $\mathrm{A}$ or $\mathrm{B}$ represents the position of the cation at the (A) or $[\mathrm{B}]$ sites. Since the $[\mathrm{B}]$ sites have high $\mathrm{Fe}^{2+}$ content and low $\mathrm{Fe}^{3+}$ content, one of the two peaks with high intensities located at 1.83 or $1.91 \mathrm{eV}$ in Fig. 3(a) and 3(b) should correspond to $\mathrm{Fe}^{2+}$ cations at the $[\mathrm{B}]$ sites and the peak with low intensity located at $2.60 \mathrm{eV}$ in Fig. 3(a) and 3(b) should correspond to $\mathrm{Fe}^{3+}$ cations at the [B] sites. On the other hand, the $\mathrm{A}-\mathrm{O}$ and B-O distances, $d_{\mathrm{AO}}$ and $d_{\mathrm{BO}}$, are about 1.90 and $2.05 \AA$. For a given cation, the transition energy from the $(\mathrm{A})$ sites to the $\mathrm{O}$ sites is therefore lower than that from [B] sites to the $\mathrm{O}$ sites, due to the distance $d_{\mathrm{AO}}$ being shorter than $d_{\mathrm{BO}}$. On the basis of these two constraints, we can obtain a relationship for the transition energies of Fe cations at the (A) and [B] sites: namely, $E_{\mathrm{tr}}\left(\mathrm{Fe}^{2+}{ }_{\mathrm{A}}\right)<E_{\mathrm{tr}}\left(\mathrm{Fe}^{2+}{ }_{\mathrm{B}}\right)<$ $E_{\mathrm{tr}}\left(\mathrm{Fe}^{3+}{ }_{\mathrm{A}}\right)<E_{\mathrm{tr}}\left(\mathrm{Fe}^{3+}{ }_{\mathrm{B}}\right)$. We can therefore identify the transition energies of various $\mathrm{Fe}$ cations for the $\mathrm{Co}_{x} \mathrm{Ni}_{0.7-x} \mathrm{Fe}_{2.3} \mathrm{O}_{4}(0.0 \leq x \leq 0.3)$ and $\mathrm{Cr}_{x} \mathrm{Ni}_{0.7} \mathrm{Fe}_{2.3-x} \mathrm{O}_{4}(0.0 \leq x \leq 0.3)$ samples, as shown in Table 3 and Fig. 3(a) and 3(b).

For $\mathrm{Fe}_{3} \mathrm{O}_{4}, E_{\mathrm{tr}}\left(\mathrm{Fe}^{2+}{ }_{\mathrm{A}}\right)=1.66 \mathrm{eV}, E_{\mathrm{tr}}\left(\mathrm{Fe}^{2+}{ }_{\mathrm{B}}\right)=1.77 \mathrm{eV}$, which are lower than those for the other two groups of samples, roughly $E_{\mathrm{tr}}\left(\mathrm{Fe}^{2+}{ }_{\mathrm{A}}\right)=1.84 \mathrm{eV}, E_{\mathrm{tr}}\left(\mathrm{Fe}^{2+}{ }_{\mathrm{B}}\right)=1.91 \mathrm{eV}$. The difference likely results from the fact that the electrons transit along the ionic chain $\mathrm{O}-\mathrm{Fe}-\mathrm{O}-\mathrm{Fe}-\mathrm{O}-\mathrm{Fe}-\mathrm{O}$ whether they are in the (A) or the [B] sublattice in $\mathrm{Fe}_{3} \mathrm{O}_{4}$, and that the electrons transit along the ionic chain O-Fe-O-M-O-Fe-O in $M \mathrm{Fe}_{2} \mathrm{O}_{4}$. This is in accord with the fact that $\mathrm{Fe}_{3} \mathrm{O}_{4}$ has a lower resistivity than doped spinel ferrites $M \mathrm{Fe}_{2} \mathrm{O}_{4}$ [25].

For the $\mathrm{Co}_{0.3} \mathrm{Ni}_{0.4} \mathrm{Fe}_{2.3} \mathrm{O}_{4}$ sample, we found a weak peak at $1.67 \mathrm{eV}$, as shown in Fig. 3(a). It is possible that this peak corresponds to $\mathrm{Co}^{2+}$ cations at $[\mathrm{B}]$ sites for which the content is 0.2 per formula. 
We have found no visible peak for $\mathrm{Cr}^{2+}$ cations. This may be due to the fact that the maximum content of $\mathrm{Cr}$ cations, $\mathrm{Cr}^{2+}$ at the [B] sites, is only 0.156 for $\mathrm{Cr}_{0.3} \mathrm{Ni}_{0.7} \mathrm{Fe}_{2} \mathrm{O}_{4}$, being less than the content ratio for those cations with visible peaks.

Obviously, more information can be obtained using the differential UV-vis absorption spectra than using the method reported in Ref. 7-11, from which only two band gap energies can be obtained。

\section{Conclusion}

We have obtained the electron transition energies between anions and various cations using differential UV-vis absorption spectra, $\mathrm{d} \alpha / \mathrm{d} E$ vs $E$. Specifically, the electron transition energies from the $\mathrm{O}$ anions to the cations $\mathrm{Ni}^{2+}{ }_{\mathrm{B}}, \mathrm{Fe}^{2+}{ }_{\mathrm{A}}, \mathrm{Fe}^{2+}{ }_{\mathrm{B}}, \mathrm{Fe}^{3+}{ }_{\mathrm{A}}$ and $\mathrm{Fe}^{3+}{ }_{\mathrm{B}}$ at the (A) or [B] sites in the (A) $[\mathrm{B}]_{2} \mathrm{O}_{4}$ spinel ferrites $\mathrm{Co}_{x} \mathrm{Ni}_{0.7-x} \mathrm{Fe}_{2.3} \mathrm{O}_{4}$, $\mathrm{Cr}_{x} \mathrm{Ni}_{0.7} \mathrm{Fe}_{2.3-x} \mathrm{O}_{4}$ and $\mathrm{Fe}_{3} \mathrm{O}_{4}$ have been determined.

\section{Acknowledgments}

This work is supported by the National Natural Science Foundation of China, under the Contract No.NSF-11174069, the Natural Science Foundation of Hebei Province (Grant No. A2015205111). The authors wish to thank Dr. Norm Davison for helpful discussion.

\section{References}

[1] S. Matzen, J.-B. Moussy, P. Wei, C. Gatel, J. C. Cezar, M. A. Arrio, Ph. Sainctavit, J. S. Moodera, Appl. Phys. Lett. 104 (2014) 182404.

[2] Y. Y. Liao, Y. W. Li, Z. G. Hu, J. H. Chu, Appl. Phys. Lett. 100 (2012) 071905.

[3] Z. Moorhead-Rosenberg, D. W. Shin, K. R. Chemelewski, J. B. Goodenough, A. Manthiram, Appl. Phys. Lett. 100 (2012) 213909.

[4] M. Reehuis, M. Tovar, D. M. Többens, P. Pattison, A. Hoser, B. Lake, Phys. Rev. B. 91 (2015) 024407.

[5] C. W. Chen, Magnetism and Metallurgy of Soft Magnetic Materials, North-Holland Publishing Company, Amsterdam. (1977) 171-417.

[6] J. M. D. Coey, Magnetism and Magnetic Materials, Cambridge University Press, Cambridge. (2010) 414-427.

[7] Jagriti Pal, Pratima Chauhan, Materials Characterization 61 (2010) 575.

[8] L. F. Hu, L. M. Wu, M. Y. Liao, X. H. Hu, X. S. Fang, Adv. Funct. Mater. 22 (2012) 998.

[9] B. Cui, H. Lin, Y. Z. Liu, J. B. Li, P. Sun, X. C. Zhao, C. J. Liu, J. Phys. Chem. C. 113 (2009) 
14083.

[10] T. A. Yousef, G. M. A. El-Reash, M. I. Attia, M. N. El-Tabai, Chem. Phys. Lett. 636 (2015) 180.

[11] T.A. Yousef, G. M. A. El-Reash, O. A. El-Gammal, R. A. Bedier, Journal of Molecular Structure 1029 (2012)149.

[12] J. Melsheimer, S. S. Mahmoud, G. Mestl, R. Schlögl, Catalysis Letters 60 (1999) 103.

[13] L. C. Xue, L. L. Lang, J. Xu, Z. Z. Li, W. H. Qi, G. D. Tang, L. Q. Wu, AIP Advances 5 (2015) 097167.

[14] G. D. Tang, Q. J. Han, J. Xu, D. H. Ji, W. H. Qi, Z. Z. Li, Z. F. Shang, X. Y. Zhang, Physica B 438 (2014) 91.

[15] H. M. Rietveld, J. Appl. Cryst. 2 (1969) 65.

[16] J. Xu, L. Ma, Z. Z. Li, L. L. Lang, W. H. Qi, G. D. Tang, L. Q. Wu, L. C. Xue, G. H. Wu, Physica Status Solidi B 252 (2015) 2820.

[17] L. L. Lang, J. Xu, W. H. Qi, Z. Z. Li, G. D. Tang, Z. F. Shang, X. Y. Zhang, L. Q. Wu, L. C. Xue, J. Appl. Phys. 116 (2014) 123901.

[18] Z. F. Shang, W. H. Qi, D. H. Ji, J. Xu, G. D. Tang, X. Y. Zhang, Z. Z. Li, L. L. Lang, Chin. Phys. B. 23 (2014) 107503.

[19] X. Y. Zhang, J. Xu, Z. Z. Li, W. H. Qi, G. D. Tang, Z. F. Shang, D. H. Ji, L. L. Lang, Physica B 446 (2014) 92.

[20] J. Xu, D. H. Ji, Z. Z. Li, W. H. Qi, G. D.Tang, X. Y. Zhang, Z. F. Shang, L. L. Lang, Phys. Status Solidi B. 252 (2015) 411.

[21] L. L. Lang, J. Xu, Z. Z. Li, W. H. Qi, G. D.Tang, Z. F. Shang, X.Y. Zhang, L. Q. Wu, L. C. Xue, Physica B 462 2015) 47.

[22] J. Xu, D. H. Ji, Z. Z. Li, W. H. Qi, G. D.Tang, Z. F. Shang, X. Y. Zhang, J. Alloys Compd. $619(2015) 228$.

[23] J. Xu, W. H. Qi, D. H. Ji, Z. Z. Li, G. D. Tang, X. Y. Zhang, Z. F. Shang, L. L. Lang, Acta Physica Sinica (in Chinese with English Abstract) 64 (2015) 017501.

[24] G. D. Tang, Z. F. Shang, X. Y. Zhang, J. Xu, Z. Z. Li, C. M. Zhen, W. H. Qi, L. L. Lang, Physica B 463 (2015) 26.

[25] D. Varshney, A. Yogi, Materials Chemistry and Physics 133 (2012) 103. 


\section{Figure captions:}

Fig. 1. X-ray diffraction patterns for the samples $\mathrm{Co}_{x} \mathrm{Ni}_{0.7-x} \mathrm{Fe}_{2.3} \mathrm{O}_{4}(\mathrm{a}), \mathrm{Cr}_{x} \mathrm{Ni}_{0.7} \mathrm{Fe}_{2.3-x} \mathrm{O}_{4}$ (b) and $\mathrm{Fe}_{3} \mathrm{O}_{4}(\mathrm{c})$.

Fig. 2. Curves of the UV-vis absorption coefficient, $\alpha$, vs wave length, $\lambda$, for samples $\mathrm{Co}_{x} \mathrm{Ni}_{0.7-x} \mathrm{Fe}_{2.3} \mathrm{O}_{4}(\mathrm{a}), \mathrm{Cr}_{x} \mathrm{Ni}_{0.7} \mathrm{Fe}_{2.3-x} \mathrm{O}_{4}(\mathrm{~b})$ and $\mathrm{Fe}_{3} \mathrm{O}_{4}(\mathrm{c})$.

Fig. 3. Curves of the differential absorption coefficient, $\mathrm{d} \alpha / \mathrm{d} E$, vs photon energy, $E=h v$, for the samples $\mathrm{Co}_{x} \mathrm{Ni}_{0.7-x} \mathrm{Fe}_{2.3} \mathrm{O}_{4}(\mathrm{a}), \mathrm{Cr}_{x} \mathrm{Ni}_{0.7} \mathrm{Fe}_{2.3-x} \mathrm{O}_{4}$ (b) and $\mathrm{Fe}_{3} \mathrm{O}_{4}$ (c). 
Table 1. Rietveld fitting results for the XRD patterns of the $\mathrm{Fe}_{3} \mathrm{O}_{4}$ and $\mathrm{Co}, \mathrm{Cr}$ doped $\mathrm{Ni}_{0.7} \mathrm{Fe}_{2.3} \mathrm{O}_{4}$ samples, where $a$ is the crystal lattice constant, $d_{\mathrm{AO}}$ and $d_{\mathrm{BO}}$ are the distances from the $\mathrm{O}$ anions to the cations at the $(\mathrm{A})$ and $[\mathrm{B}]$ sites, and $d_{\mathrm{AB}}$ is the distance from the cations at the $(\mathrm{A})$ sites to those at the [B] sites.

\begin{tabular}{ccccc}
\hline$x$ & $a(\AA)$ & $d_{\mathrm{AO}}(\AA)$ & $d_{\mathrm{BO}}(\AA)$ & $d_{\mathrm{AB}}(\AA)$ \\
\hline $\mathrm{Fe}_{3} \mathrm{O}_{4}$ & 8.388 & 1.880 & 2.061 & 3.478 \\
\hline $\mathrm{Co}_{x} \mathrm{Ni}_{0.7-x} \mathrm{Fe}_{2.3} \mathrm{O}_{4}[13]$ \\
\hline 0.00 & 8.348 & 1.894 & 2.038 & 3.461 \\
0.10 & 8.355 & 1.896 & 2.040 & 3.464 \\
0.20 & 8.359 & 1.897 & 2.041 & 3.465 \\
0.30 & 8.365 & 1.898 & 2.042 & 3.468 \\
\hline $\mathrm{Cr}_{x} \mathrm{Ni}_{0.7} \mathrm{Fe}_{2.3-x} \mathrm{O}_{4}[13]$ & & \\
\hline 0.00 & 8.352 & 1.895 & 2.039 & 3.462 \\
0.05 & 8.349 & 1.894 & 2.038 & 3.461 \\
0.10 & 8.347 & 1.894 & 2.038 & 3.461 \\
0.15 & 8.347 & 1.894 & 2.038 & 3.461 \\
0.20 & 8.345 & 1.894 & 2.037 & 3.460 \\
0.25 & 8.343 & 1.893 & 2.037 & 3.459 \\
0.30 & 8.341 & 1.893 & 2.036 & 3.458 \\
\hline \multicolumn{5}{l}{}
\end{tabular}


Table 2. Cation distributions in the $\mathrm{Fe}_{3} \mathrm{O}_{4}$ and $\mathrm{Co}, \mathrm{Cr}$ doped $\mathrm{Ni}_{0.7} \mathrm{Fe}_{2.3} \mathrm{O}_{4}$ samples estimated using the $\mathrm{O} 2 \mathrm{p}$ itinerant electron model.

\begin{tabular}{cccc}
\hline & $\mathrm{Fe}_{3} \mathrm{O}_{4}$ & $\mathrm{Co}_{0.3} \mathrm{Ni}_{0.4} \mathrm{Fe}_{2.3} \mathrm{O}_{4}$ & $\mathrm{Cr}_{0.3} \mathrm{Ni}_{0.7} \mathrm{Fe}_{2} \mathrm{O}_{4}$ \\
\hline (A) site & & & \\
\hline $\mathrm{Fe}^{2+}$ & 0.584 & 0.403 & 0.269 \\
$\mathrm{Fe}^{3+}$ & 0.416 & 0.457 & 0.494 \\
$\mathrm{Ni}^{2+}$ & --- & 0.038 & 0.051 \\
$\mathrm{Co}^{2+}$ & --- & 0.037 & --- \\
$\mathrm{Cr}^{2+}$ & --- & --- & 0.046 \\
$\mathrm{Ni}^{3+}$ & --- & 0.032 & 0.070 \\
$\mathrm{Co}^{3+}$ & --- & 0.033 & -- \\
$\mathrm{Cr}^{3+}$ & --- & --- & 0.070 \\
\hline$[\mathrm{B}] \mathrm{site}^{3+}$ & & & \\
\hline $\mathrm{Fe}^{2+}$ & 1.384 & 1.099 & 1.032 \\
$\mathrm{Fe}^{3+}$ & 0.616 & 0.342 & 0.205 \\
$\mathrm{Ni}^{2+}$ & --- & 0.300 & 0.542 \\
$\mathrm{Co}^{2+}$ & --- & 0.200 & --- \\
$\mathrm{Cr}^{2+}$ & --- & -- & 0.156 \\
$\mathrm{Ni}^{3+}$ & --- & 0.030 & 0.037 \\
$\mathrm{Co}^{3+}$ & --- & 0.029 & --- \\
$\mathrm{Cr}^{3+}$ & --- & --- & 0.029 \\
$\mathrm{Ref}^{3+}$ & {$[14]$} & {$[13]$} & {$[13]$} \\
\hline
\end{tabular}


Table 3. The electron transition energies of $\mathrm{Ni}^{2+}, \mathrm{Fe}^{2+}, \mathrm{Fe}^{3+}$ cations in $\mathrm{Fe}_{3} \mathrm{O}_{4}$ and the $\mathrm{Co}, \mathrm{Cr}$ doped $\mathrm{Ni}_{0.7} \mathrm{Fe}_{2.3} \mathrm{O}_{4}$ samples. The subscripts A or B represent the position of the cation at the (A) or [B] sites. The energy errors are less than $\pm 0.01 \mathrm{eV}$.

\begin{tabular}{cccccc}
\hline sample & $\mathrm{Ni}^{2+}{ }_{\mathrm{B}}$ & $\mathrm{Fe}^{2+}{ }_{\mathrm{A}}$ & $\mathrm{Fe}^{2+}{ }_{\mathrm{B}}$ & $\mathrm{Fe}^{3+}{ }_{\mathrm{A}}$ & $\mathrm{Fe}^{3+}{ }_{\mathrm{B}}$ \\
\hline $\mathrm{Co}_{x} \mathrm{Ni}_{0.7-x} \mathrm{Fe}_{2.3} \mathrm{O}_{4}$ & 1.64 & 1.84 & 1.91 & 2.14 & 2.55 \\
$\mathrm{Cr}_{x} \mathrm{Ni}_{0.7} \mathrm{Fe}_{2.3-x} \mathrm{O}_{4}$ & 1.64 & 1.83 & 1.91 & 2.15 & 2.56 \\
$\mathrm{Fe}_{3} \mathrm{O}_{4}$ & --- & 1.66 & 1.77 & 2.14 & 2.57 \\
\hline
\end{tabular}




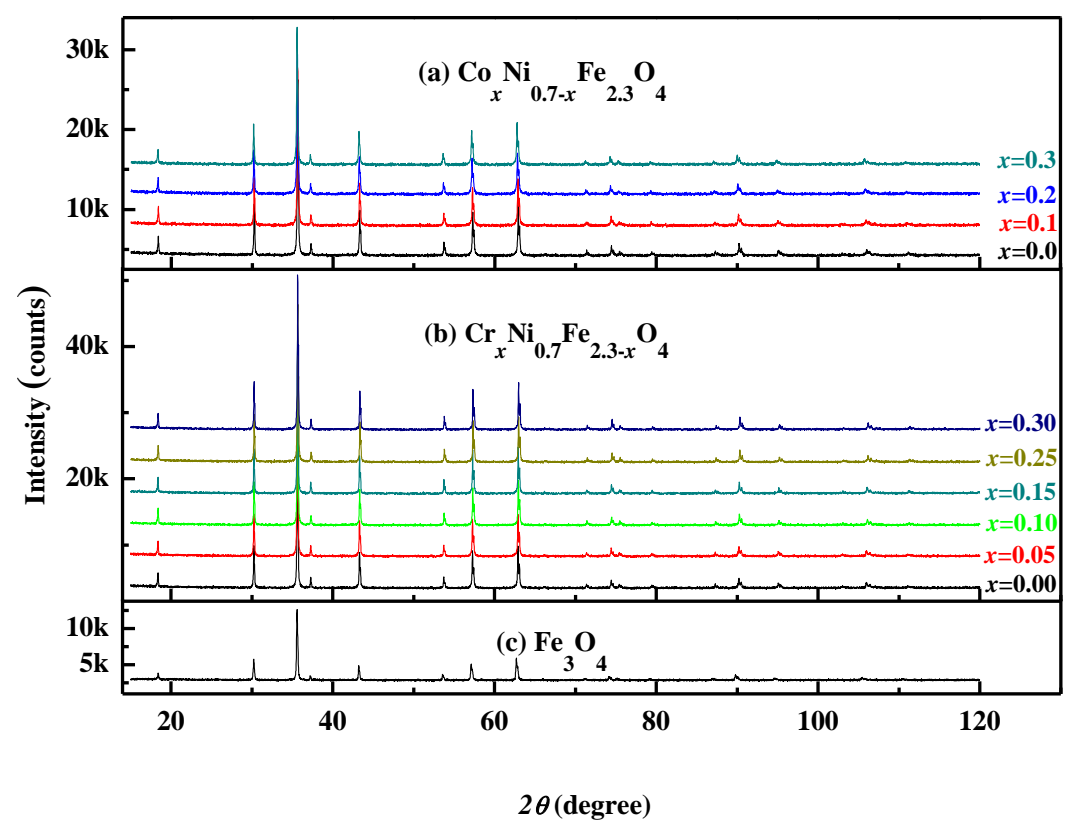

Fig. 1 

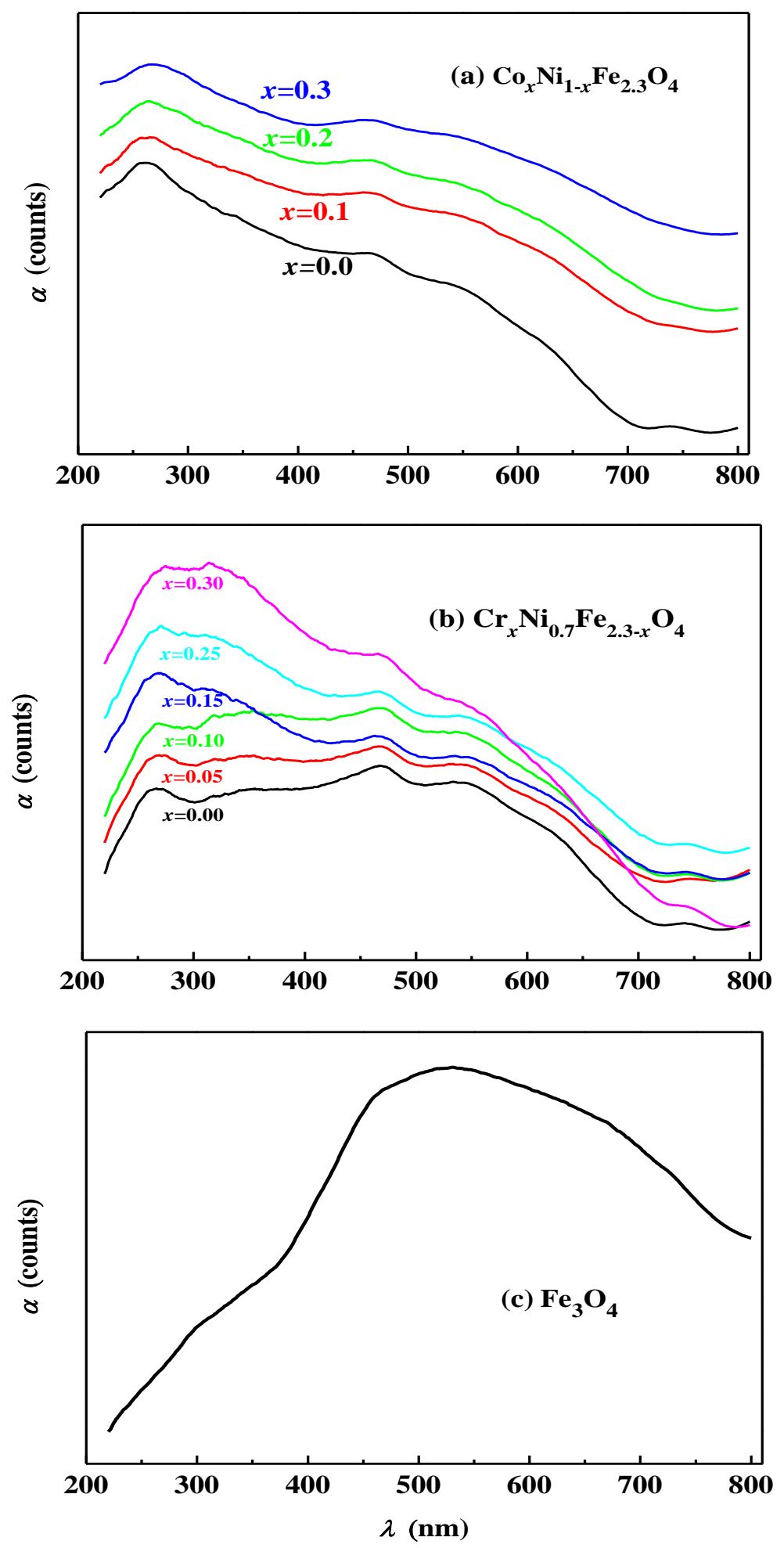

Fig. 2 

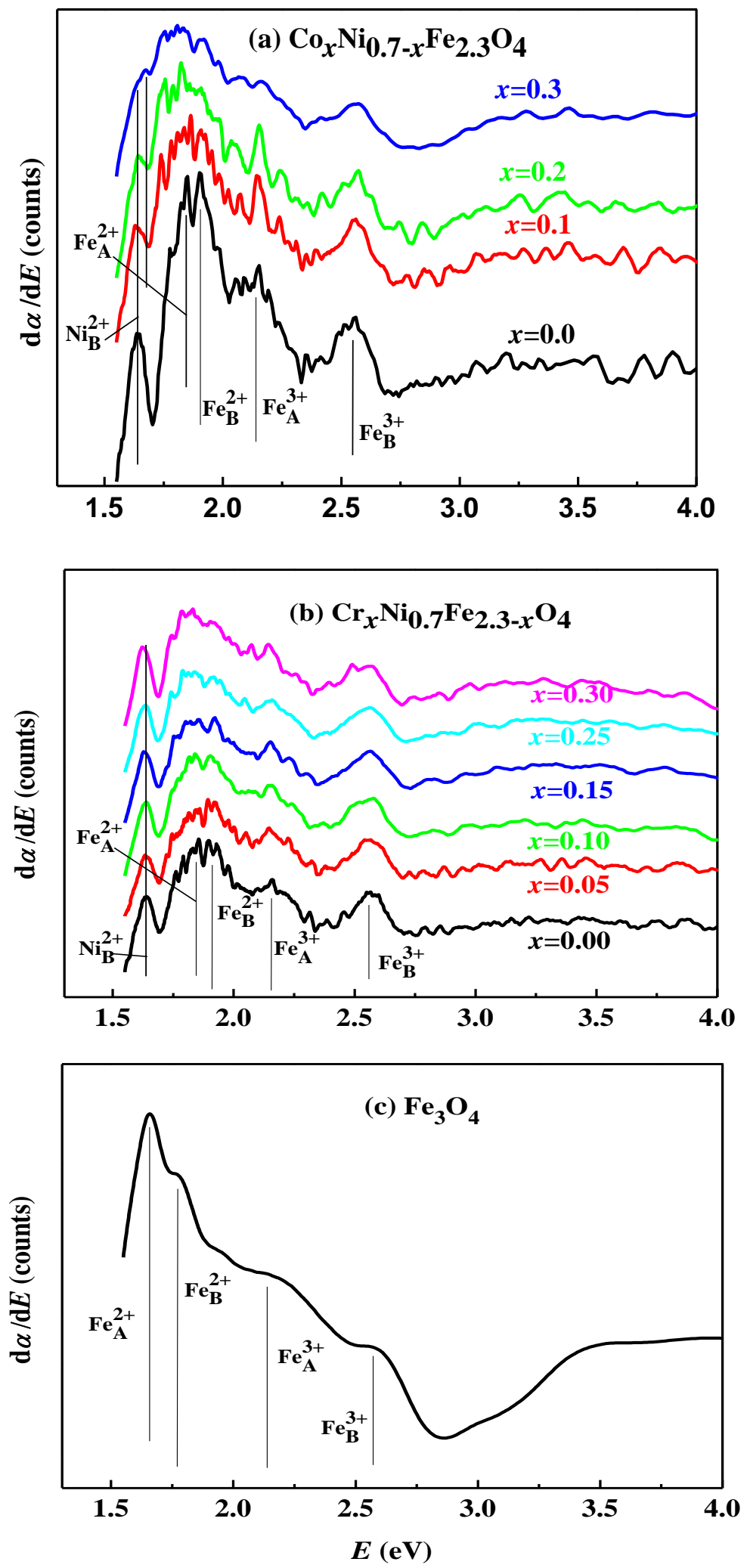

Fig. 3 